\title{
Subject Recruiter
}

National Cancer Institute

\section{Source}

National Cancer Institute. Subject Recruiter. NCI Thesaurus. Code C51881.

A person whose task is to identify and enroll individuals into a research study. 